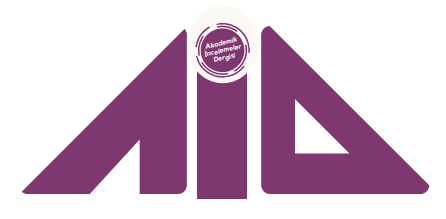

\title{
Dini Radikalizmin Ana Akım İslamcılara Yönelttiği Tenkitler d
}

\author{
The Criticisms of Religious Radicalism Against Mainstream \\ Islamists
}

\author{
Nurullah ÇAKMAKTAS \\ Dr. Arș. Gör., Marmara Üniversitesi, \\ Orta Doğu ve İslam Ülkeleri Araştırmaları Enstitüsü, \\ nurullah.cakmaktas@marmara.edu.tr \\ https://orcid.org/0000-0001-5493-419X
}

\section{Araștırma \& Yayın Etiği \\ Bu makale en az iki hakem tarafindan incelenmiș, iThenticate yazılımı ile taranmıș, araștırma yayın ve etiğine aykırıık tespit edilmemiștir.}

\section{BY-NC 4.0}

Bu makale Creative Commons Attribution-NonCommercial License altında lisanslanmıștır.

This paper is licensed under a Creative Commons Attribution-NonCommercial License

\section{Research \& Publication Ethics}

This article was reviewed by at least two referees, a similarity report was obtained using iThenticate, and compliance with research/publication ethics was confirmed.

\section{Copyright $(c$}

Sakarya Üniversitesi, Sosyal Bilimler Enstitüsü, Sakarya/TÜRKIYE

Sakarya University, Institute of Social Science, Sakarya/TURKEY

\section{Atıf/Citation}

Çakmaktaș, Nurullah . "Dini Radikalizmin Ana Akım İslamcılara Yönelttiği Tenkitler". Akademik Incelemeler Dergisi 16 / 1 (Nisan 2021): 26-46. https://doi.org/

10.17550/akademikincelemeler.870070

Makale Türü/Article Type: Araştırma Makalesi/Research Article

Geliş Tarihi/Date Received: 28.01.2021

Kabul Tarihi/Date Accepted: 24.03.2021

Yayın Tarihi/Date Published: 15.04.2021

ISSN: $\quad 1306-7885$

E-ISSN: $2602-3016$

Cilt/Volume: 16 | Sayı/Issue: 1 |

Yll/Year: 2021 (Nisan/April) 


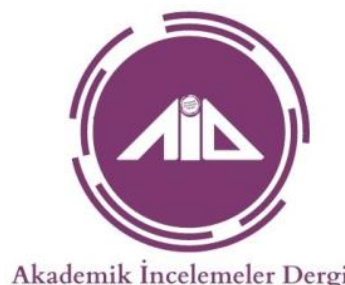

Dini Radikalizmin Ana Akım İslamcılara Yönelttiği Tenkitler

Öz

$\mathrm{Bu}$ araştırma, ana akım İslamcılık düşüncesinin ve İslami hareketin bir sapması olarak altmışlı yıllardan sonra İslam dünyasında teşekkül eden dini radikal düşüncenin, İhvan-ı Müslimin bașta olmak üzere ana akım İslamcılık düşüncesine ve İslamcılara yönelttiği tenkitleri incelemektedir. Her iki ekolün İslam dünyasını ve Müslüman toplumu ilgilendiren sorunlara teo-politik hassasiyetle reaksiyon gösteriyor olmaları, bu iki ekolün zaman zaman "siyasal İslam" tanımlaması altında aynı kategoriye dâhil edilmesine neden olabilmektedir. Bu çalışmanın temel amacı; dini radikalizmin birincil metinlerini inceleyip analiz etmek suretiyle her iki ekolün pek çok meselede tam bir karşıtlık içinde olduğunu, Ömer Abdurrahman, Eymen ez-Zevâhiri, Ebû Muhammed el-Makdîsî, Ebû Mus'ab es-Sûrî ve Ebû Yahya el-Lîbî gibi öncü cihâdî selefi ideologların ana akım İslamcılara yönelttiği tenkitler üzerinden göstermeye çalıșmaktır. Bu çalıșmada söz konusu bu tenkitler; "Din-Siyaset İlişkisi Bağlamında", "Din-Hukuk İliş̧kisi Bağlamında" ve "İslamlaşma Yöntemi Sorunsalı ve Ötekiyle İlişki Bağlamında" olmak üzere üç ana başlık altında incelenmiştir.

Anahtar Kelimeler: Dini Radikalizm, Cihâdî Selefilik, İslamcllık, İhvan-ı Müslimin

\title{
The Criticisms of Religious Radicalism Against Mainstream Islamists
}

\begin{abstract}
This study examines the criticisms of the religious radical thought that emerged in the Islamic world after the sixties as an anomaly of the mainstream Islamism and the Islamic movement, directed against mainstream Islamism and Islamists, especially the Ikhwan-i Muslimin. The fact that both schools of thought react to the problems concerning the Islamic world and Muslim society with theopolitical sensitivity, causes these two schools to be included in the same category under the definition of "political Islam" from time to time. The main objective of this article is to try to demonstrate that both schools are in complete opposition on many issues through the criticisms of the jihadi salafi ideologues like Omar Abdurrahman, Ayman al-Zavahiri, Abu Muhammed al-Makdîsî, Abu Musab alSurî and Abu Yahya al-Libi against mainstream Islamists by examining the primary texts of religious radicalism. In this study, these criticisms are examined under three main headings: "In the Context of the Relationship between Religion and Politics", "In the Context of the Relationship between Religion and Law" and "In the Context of the Problem of Islamization Method and the Relationship with the Other".
\end{abstract}

Keywords: Religious Radicalism, Jihadi Salafism, Islamism, The Muslim Brotherhood 


\section{Giriş}

On sekizinci yüzyılın sonlarından yirminci yüzyılın ortalarına kadar sömürge ve işgal tecrübesi yașamış Müslüman devletler, yirminci yüzyılın ilk yarısında istiklal savaşları vermek suretiyle batılı güçleri topraklarından uzaklaştırmayı başarabilmişlerdir. Fakat bağımsızlıklarının akabinde, Batı'nın fikrî teklifleri Müslüman ülkelerde karşılık bulmuş ve modern siyasal ideolojiler yeni ulus devletlerin dayanağı olmuştur. On dokuzuncu yüzyılda sömürgeciliğe ve batının söz konusu fikrî tekliflerine reaksiyon olarak şekillenen İslamcılık, yirminci yüzyılın ortalarından itibaren batılılaşmayı savunan yeni ulus devletlere karşı düşünce üretimi içine girmiş ve dini-siyasi bir hareket hüviyetine de bürünerek aksiyon kazanmıştır. Öyle ki bu süreç içerisinde İslamcılık entelektüel meşgale sınırını aşmış, aksiyon kazanmıș ve böylece İslami hareket zuhur etmiştir.

Kurulan yeni ulus devletlerin benimsediği seküler politikalara karşı İslami hareket müntesipleri, devletin ve toplumun İslamlaşması için takip edilmesi gereken yöntem hususunda zaman içinde anlaşmazlık içine düşmüş ve bu durum İslami hareketin çeşitli fraksiyonlara ayrılmasıyla sonuçlanmıştır. Öyle ki ıslah, terbiye, irşat ve davet ilkelerini yozlaşmayla mücadele ve İslamlaşma yöntemi olarak savunan bir kesim kendilerini siyaset dışı olarak konumlandırmıştır. Bireylerin davranış eğitimini önceleyen sûfî gruplar, dini inançları saflaştırmayı ve hadis eksenli din eğitimini merkeze alan geleneksel selefi gruplar ve ülke ülke dolaşarak İslam'ı anlatmaya çalışan gezgin tebliğ ve davet cemaatleri bu grubun en önemli temsilcileri kabul edilmektedir.

Başka bir kesim ise Müslüman toplumların içinde bulunduğu krizin temelde siyasi kaynaklı olduğunu düşünmüş, krize çözüm üretmenin ve İslamlaşmanın ise ancak siyasal mücadele içine girmekle mümkün olabileceğini savunmuştur. "Siyasetin içinde kalarak İslamlaşma" şeklinde tarif edilmesi mümkün bu ekol aslında İslamcılık düşüncesinin ve İslami hareketin ana eksenini oluşturmuş ve "ana akım İslamcılık düşüncesi ve İslami hareket” olarak tanımlanmıştır. Yirminci yüzyılın ilk yarısında Mısır'da kurulan İhvan-ı Müslimin ile Pakistan'da kurulan Cemaat-i İslami grupları bu ekolün ilk temsilcileridir. Moderniteye karşı onun içinde kalarak çözüm üretmeye çalışan bu ekolün ortaya koyduğu düşünce biçimi, benzer sorunları yaşayan Müslüman topraklarda da makes bulmuş, kısa süre içinde bu metodu benimseyen gruplar muhtelif ülkelerde neşvünema bulmuştur.

Din temelli alternatif bir siyasal söyleme sahip ana akım İslami hareketin yeni ulus devletler tarafından bir tehdit unsuru olarak algılanması, buna bağlı olarak yargılama, mahkûmiyet, işkence, idam ve faaliyetlerin yasaklanması gibi sert baskı politikalarıyla sindirilmeye çalışılması ve ana akım İslami hareketin de buna mukabil siyasetin içinde kalma ve "İslamlaşmanın tedriciliği" yöntemini savunmaya devam etmesi, hareket içinde özellikle sert hapishane atmosferini tecrübe etmiş ve öfkelenmiş bazı üyelerden itirazların yükselmesine zemin hazırlamıştır. Bu kimseler maruz kaldıkları sert politikalara karşı aynı sertlikle cevap vermeyi teklif etmiş, İslamlaşmanın tedrici bir yolla değil de ancak silahlı devrim yoluyla mümkün olabileceğini savunmuşlardır. Ana akım İslami hareket içindeki söz konusu yöntem ihtilafı ilk olarak tam anlamıyla altmışlı yıllarda yaşanmış, bu ihtilaf neticesinde ana akım İslamcılık düşüncesinin bir sapması (anomali) olarak dini radikal düşünce teşekkül etmeye başlamış ve bu gelişmeler dini-radikal yeni fraksiyonların oluşumuyla sonuçlanmıştır. 
Söz konusu ayrışmanın yaşandığı altmışlı yıllardan günümüze dek, cihâdîlik, cihâdî selefilik veya İslamî Radikalizm gibi isimlerle adlandırılan teo-politik düșünce ve bu düşüncenin ideologları olarak kabul edilen kimseler, yine dini-siyasi bir hareket olan ana akım İslamcılık düşüncesine ve bu düşüncenin ideologlarına ihtilafa konu olan belli başlı temalarda eleştiriler yöneltmiștir. Biz bu çalışmamızda dini radikalizmin ana akım İslamcılık düșüncesine ve İslamcılara yönelttiği tenkitleri "Din-Siyaset İlişkisi Bağlamında", "Din-Hukuk İlişkisi Bağlamında" ve "İslamlaşma Yöntemi Sorunsalı ve Ötekiyle İlişki Bağlamında" olmak üzere üç ana başlık altında incelemeyi uygun bulduk.

Her iki ekolü de harekete geçiren temel hassasiyetin siyasal alana dair meseleler olması, zaman zaman ana akım İslamcılar ile dini radikal gruplar arasında özdeşlik kurulma hatasına neden olabilmiştir. Özellikle "siyasal İslam" kavramının her iki ekol için bir tanımlama aracı olarak kullanılması, bu özdeşlik kurma sorunsalının en bariz görünümü olarak dikkat çekmektedir. Oysa İslam dünyasında ortaya çıkan dini radikal düşünce; her ne kadar 19. ve 20. yüzyılda şekillenmiş ana akım İslamcılık düşüncesinden etkilenmiş, ondan beslenmiş ve onun bir sapması olarak teşekkül etmiş olsa da, modern Müslüman toplumu doğrudan ilgilendiren pek çok meselede söz konusu ekol, ana akım İslamcılık düşüncenin tam karşısında yer almıştır. Biz de bu çalışmamızda her iki ekolü özdeşleștirmenin mümkün olmadığını, dini radikalizmin ideologları olarak kabul edilen kimselerin bizzat kaleme aldıkları metinlerde ana akım İslamcılara yönelttiği tenkitlerin izini sürerek göstermeye çalışacağız.

Çalışmamız; araştırılması hedeflenen olgular hakkında bilgi içeren yazılı materyallerin toplanması, yorumlanması ve analizi anlamına gelen dokümantasyon yöntemi kullanılarak hazırlanmıștır. Araștırmamız temelde dini radikalizmin ürettiği düşünceye odaklandığı ve bu düşünceye de bir bütün olarak ancak yazılı metinlerle ulaşılabildiği için gözlem, anket ve mülakat gibi diğer nitel araştırma teknikleri yöntemimizin dıșında tutulmuştur. Çalışmamız; Seyyid Kutup, Ömer Abdurrahman, Eymen ez-Zevâhiri, Ebû Muhammed el-Makdîsî, Ebû Mu'ab es-Sûrî ve Ebû Yahya el-Lîbî gibi dini radikal düşünce ideologları olarak kabul edilen öncü isimlerin ürettiği birincil kaynaklar incelenerek hazırlanmıştır.

\section{Din-Siyaset İlișkisi Bağlamında Yöneltilen Tenkitler}

İslam dünyasında ulus devlet sonrası dönemde Müslüman toplumları doğrudan etkileyen bir takım siyasal meseleler, gerek ana akım İslamcılık düşüncesinin ve gerekse de dini radikal düşüncenin şekillenmesinde başat etken olarak dikkat çekmektedir. Her iki düşünce ekolünü de motive eden ve harekete geçiren, bu ekollere mensup kimselerin sahip olduğu teo-politik hassasiyetler olmuştur. Bu iki ekolün ortak paydası, İslam'ın siyasal alana dair söyleyecek sözü olduğu iddiasını taşımalarıdır. Fakat siyasal alana dair İslamlaşmanın hangi yöntem ile gerçekleșeceği sorusuna verilen cevap, iki ekol arasındaki ayrışmayı tetikleyen ve derinleştiren en önemli unsur olmuştur. Öyle ki ana akım İslamcılık cari sistem içinde kalarak tedrici bir yolla İslamlaşmayı savunurken, dini radikal düşünce ise silahlı bir kalkışma ile İslamlaşma devriminin gerçekleşebileceğini savunmuştur. Bu temel ayrışmadan mütevellit cihâdi ideologlar olarak isimlendirilen dini radikalizm öncüleri, yetmişli yıllardan bu yana İhvan-ı Müslimin başta olmak üzere ana akım İslamcılara mevcut siyasal düzen ile olan ilişkileri nedeniyle pek çok eleştiri yöneltmişlerdir. 
Dini radikal düşüncenin bu süreçte İhvan özelinde ana akım İslami harekete dinsiyaset ilişkisi bağlamında yönelttiği en baskın tenkitlerin biri demokrasi meselesi etrafında olmuştur. Ana akım İslami hareketin; cari politik sistem içinde var olmaya çalışması, müesses nizamın koyduğu kurallar çerçevesinde siyasal mücadelesini vermesi ve iktidara gelmek için mevcut araçları kullanmayı tercih etmesi; İslamlaşma yöntemi olarak silahlı mücadeleyi ve şiddeti bir değişim ve dönüşüm aracı olarak gören dini radikal düşüncenin ve bu düşünceyi benimseyen grupların tepkisine neden olmuştur. Hâkim siyasal paradigma içinde de demokrasi konusu eleștirilerin en çok odaklandığı mesele olmuştur.

Özellikle yetmişli yıllardan sonra teo-politik radikal düşünce içinde önemli yere sahip pek çok ideolog, demokrasiyi din dışı bir düşünce ve uygulama biçimi olarak kabul etmiş ve onun İslamî akidenin temeli olan "tevhit" ilkesine halel getirdiğini savunmuştur. Zira onlara göre demokrasi, çoğunluğun talep ve iradesine göre hükümde bulunmayı kendine şiar edinmiş ve bu iradeyi Allah'ın indirdiği hükümlerin önüne koymuştur. Öyle ki bu durum, toplum iradesini Allah'a şirk koşmak anlamına gelmektedir. Ayrıca demokrasi, insanlara yasama yetkisi vermek suretiyle beşeri ilahlaştırmakta ve böylece yeni bir din ihdas etmektedir. Dolayısıyla demokrasi bir küfür dini olarak İslam'ın karşısında kendisine pozisyon açan müstakil bir din olarak addedilmiştir. Öyle ki yasama yetkisi vermek suretiyle beșeri ilahlaştıran kimse demokrasi dinine girmiş olur ki bunun anlamı bu kimsenin İslam dairesi dışına çıkıp kâfir olmasıdır. İslam ve demokrasi tam anlamıyla birbirlerinin karşıtıdırlar ve bir kimsenin aynı anda hem İslam'a ve hem de demokrasiye insanları davet etmesi mümkün değildir (Ez-Zevâhirî, 2005, 31-36; El-Makdîsî, ts., 11-13; EtTartûsî, 1999, 1-2; El-Lîbî, ts., 7-8; Eş-Şankîtî, 2011, 7-10).

Diğer taraftan bu kimseler nezdinde demokrasi, Batı menșeli bir tecrübenin ürünü olarak görülmüş olması onun reddinin gerekçesi olarak da sunulmuştur. Öyle ki bu kimselere göre; Batı'nın papalık ve ruhbanlık tarihi tecrübesi içinde bir anlam ifade eden demokrasi kavramı, İslam toplumu için aynı anlamı ifade etmemektedir. Ayrıca batının demokrasiyi İslam dünyasına ihraç çabaları, ona hâkim olma araçlarından bir tanesidir. Zira Batı ilk olarak doğrudan sömürge yoluyla, daha sonra diktatörleri kullanarak dolaylı sömürge yoluyla ve son olarak da demokrasi yoluyla İslam dünyasına hâkim olmaya çalışmış ve çalışmaya devam etmektedir. Öyle ki Batı; demokrasi ihraç ederken onu İslam kültürünün bir alternatifi olarak inşa etmeye çalışmakta, bu modeli Müslüman topraklara dikta etmekte ve böylece demokrasinin oluşturduğu seküler atmosferi kullanarak Müslüman toplumun yozlaşmasını hedeflemektedir (Eş-Şankîtî, 2011, 19-21).

El-Makdîsî̀ye göre demokrasi, tamamen halkın iradesini yansıtan masum bir sistem olmayıp batılı fikir ve ideolojilere yaslanan "tağutî" rejimlerin kontrolü altındadır. Öyle ki ona göre şayet toplumun iradesi ve talepleri, söz konusu rejimlerin çıkarları ile çatışma içine girerse bu durumda o irade demokratik bir hak olarak kabul görmeyecektir. Mesela çoğunluğun talebi şeriat kanunlarının tatbiki yönünde olsa bile demokratik özgürlük, söz konusu talebi karşılama esnekliğini gösteremeyecektir (El-Makdîsî, ts., 13-15). Teo-politik radikal düşüncenin etkili isimlerinden Ebû Yahya El-Lîbî de demokrasi alanını, sınırlarını müesses nizamların belirlediği bir tiyatro sahnesine ve bir oyuna benzetmektedir (El-Lîbî, ts., 4-5).

Yine el-Lîbî demokrasinin eşit bir siyasal ortam sunması ve bunun neticesinde "din düşmanı bir komünistin" veya "laik birinin" iktidarına olanak sağlaması nedeniyle kabul edilemez olduğunu vurgulamıştır. Ayrıca o, demokratik sistemlerde hukuk 
önünde Müslüman ile Gayrimüslimlerin eşit olması nedeniyle ortadan kalkan sinırlara dikkat çekmiş ve bu durumun dinen reddedildiğini ifade etmiştir. Keza o; demokrasilerde, İslam hukuku içinde önemli yeri olan ceza hukuku ile zimmi hukukun, el-Velâ ve'l-Berâ gibi Kuranî ilkelerin ve bütün türevleriyle Allah yolunda cihat ibadetinin uygulanamayacağını vurgulayarak demokrasinin din dıșı olduğunu göstermeye çalışmıştır (El-Lîbî, ts., 3).

Dini radikal düşüncenin diğer bir etkin ismi Ebû Basir et-Tartûsî de demokrasinin; sınırsız inanç özgürlügü sağlaması, kutsala hakarete dahi müsamaha gösteren ifade özgürlüğü sunması, bütün boyutlarıyla laiklik ve sekülerizmle iç içe geçmesi, bütün kötülük ve fuhşiyatı bireysel özgürlük kapsamında kabul etmesi, Müslüman ve Gayrimüslimi hukuk önünde eşit tutması, hangi ideolojik değerlerin propagandasını yapacağına bakmaksızın insanlara gruplaşma ve partileşme özgürlüğü sunması, hakikati temsil edip etmediğine bakmaksızın çoğunluğun fikrine itibar etmesi ve kaynağının helal veya haram olduğundan bağımsız kazanç hakkı tanıması gibi pek çok nedenden dolayı İslam'a mugayir ve kabul edilemez olduğunu ifade eder (EtTartûsî, 1999, 2-8).

Pek çok cihâdî-selefi ideolog, İhvan gibi ana akım İslamcıların demokratik sistem içinde siyasal mücadele vermelerinin dini meşruluğunu ispatlamak için ileri sürdükleri argümanlara itiraz da etmiştir. Söz konusu İslamclların, özellikle siyasal katılıma ve hatta yönetimde görev almaya olanak sağlayan demokrasiyi Kuran'daki şûra ayetleri ile meşrulaştırmaya çalışmaları ve demokrasinin İslam ile uyumlu olduğunu iddia etmeleri, bu kimselerin eleştirilerini şiddetlendirdiği odak nokta olmuştur. Mesela el-Makdîsî, şûra ve demokrasinin tam anlamıyla birbirinden farklı şeyler olduğunu iddia etmiş ve dolayısıyla Müslümanları demokrasiye davet etmenin şûraya davet etmekle aynı anlama gelmediğini ifade etmiștir. Öyle ki ona göre şûra, herhangi bir konuda bir hüküm verilmeye niyetlenip de dinin ana metinlerinde bu konu etrafında bir hüküm bulunmadığı durumlarda, yöneticinin, etrafındaki âkil ve bilge sahibi kimselerle görüş alışverişinde bulunup çoğunluğun fikrini kabul etme zorunluluğu olmaksızın Allah'a tevekkül ederek hüküm vermesi anlamına gelen dini bir yöntemdir. Demokrasi ise bizzat toplumu en güçlü karar verici kabul ederek çoğunluğun görüşünü nazarı itibara almak suretiyle kurallar koyan bir siyasal sistemin adıdır. Allah'a tevekkül ederek bir kararda bulunmak şûra uygulamasının merkezinde yer alırken çoğunluk ve çoğunluğun görüşü, söz konusu siyasal sistem içinde demokrasinin tanrısı olarak kabul görmektedir (El-Makdîsî, ts., 31-37).

Diğer taraftan el-Lîbî de ana akım İslamcıların şûrayı desteklemekle kalmadıklarını, kendilerine yöneltilen "şayet demokratik sistemde halk kâfir birini veya dini tam anlamıyla dışlayan komünist bir partiyi seçerse tavrınız ne olur" mealindeki soruya "bize düşen halkın tercihine ve seçimine saygı duymaktır" şeklinde verdikleri cevabın altını çizmiş ve İslamcıları hak ile batılı birbirine karıștırmakla ve inananların zihinlerini bulandırmakla suçlamıştır (El-Lîbî, ts., 8-9). Yine eş-Şankîtî de demokrasi ile şûra uygulamalarını birbirine karıştırmanın iman ile küfrü veya hak ile batılı birbirine karıştırmakla aynı șey olduğunu iddia etmiştir (Eş-Şankîtî, 2011, 5).

Bazı öncü cihâdî selefi ideologlar, İslamcıların demokrasinin temel ilkelerinden olan "inanç özgürlüğü" ilkesi ile Kuran'daki "dinde zorlama yoktur" ayeti arasında benzerlik kurma çabalarını da tenkide tabi tutmuşlardır. Zira onlara göre demokrasinin "inanç özgürlüğü" ilkesi İslami anlayıșa tam anlamıyla zıttır. Öyle ki 
sadece başlı başına ridde hükmü, yani İslam'a göre dinden çıkan birinin öldürülmesi hükmü, demokrasilerdeki inanç özgürlüğü ilkesinin İslam ile uyumlu olduğu iddiasını çürütmektedir. Ayrıca İslam beldesinde yaşayan Ehl-i Kitap cizye vergisi vermek zorundayken paganistler ise ya Müslüman olmak ya da savaşa muhatap olmak mecburiyetindedir. Dolayısıyla İslam beldesinde demokrasinin sunduğu şekliyle bir inanç özgürlüğü söz konusu değildir (Et-Tartûsî, 1999, 2; El-Lîbî, ts., 56).

İhvan-ı Müslimin gibi ana akım İslamcılar, siyasetin içinde kalarak parlamentoda mansıp sahibi olmanın; İslamî davetin önündeki engelleri kaldırma, dindarların maruz kaldığı baskıları azaltma, İslami hakikati dile getirme ve yayma gibi hususlarda bir imkân tanıdığını ve bu durumun Müslümanların menfaatine olduğunu her daim kendilerini tenkit eden radikal unsurlara karşı argüman olarak kullanmışlardır. El-Makdîsî ise İhvan'ın bu argümanlarına da itiraz etmektedir. Öyle ki ona göre, İslam'da dinin asli unsuru kabul edilen tevhit inancl, söz konusu siyasal sistem içinde yok sayılmaktadır. Hal böyleyken diğer tâli meselelerde birtakım kazanımlar elde etmek, dinin maslahatı için pek bir anlam ifade etmemektedir. Zira tâli bir maslahat için asıl olandan vazgeçmek kabul edilemez bir anlayıştır. Ayrıca el-Makdîsî’ye göre; dindarların faydasına olan bir meseleyi, hâkim siyasal düzenin anayasasına uygun hale getirme zorunluluğu ise bir tenakuzu ifade etmektedir. Müslümanların maslahatı için bu metot etrafında çabalayanlar ona göre, tağuti sistemlerin oyuncağı haline gelmiştir. Nitekim el-Makdîsî; Mısır, Cezayir ve Kuveyt'te siyasal katılım yanlısı İslamcıların nasıl başarısız olduklarını, kendi görüşünü desteklemek adına örnek vakalar olarak sunmaktadır (El-Makdîsî, ts., 4247).

Yine El-Makdîsî; ana akım İslami hareketin, mevcut siyasi düzen içinde faaliyette bulunmanın Müslümanların yararına olduğunu ispatlamaya matuf argümanlarını aktardıktan sonra eski ulemaya referansta bulunarak bu metot anlayışını İblisin bir tuzağı olarak tanımlamıştır. Ona göre, günümüz tağutları ile kıyaslanamayacak derecede daha ehven olmalarına rağmen eski ulemanın kendi dönemlerindeki yöneticilere karşı olan tavrı son derece açık ve nettir. Bugünkülerin aksine selef uleması, devlet idarecilerinden uzak durmayı, onları daha rahat tenkit edebilmek adına zaruri görmekteydi. Hatta bir ikrama mazhar olurlar da onlara karşı bir yumuşama gösterirler endişesiyle iyiliği emretmek ve kötülükten sakındırmak amacıyla dahi olsa onların yanına gitmeyi hoş görmemişlerdir (El-Makdîsî, 1984, 27-28). Öyle ki onların bu mekânlardan uzak kalması sadece zulmün ve haksızlığın olduğu dönemlerde vuku bulmamıș, doğru yol üzere șeriata tabi olan yöneticilerin iktidarda olduğu dönemde de bu tavır devam etmiştir (El-Makdîsî, 1984, 35).

Ebu'l-Munzir_eş-Şankîtî de ana akım İslamcıların demokrasinin İslamlaşma yolunda bir araç olarak kullanılabileceği iddiasına itirazda bulunmuştur. Ona göre hiçbir Müslüman ülkenin demokrasi tecrübesi İslamlaşma adına bir fayda sağlamamış ve bu anlayış üzerinde yol alınarak bir İslam devleti inşa edilememiștir. Kaldı ki ona göre demokrasiyi İslamlaşma yolunda bir vesile olarak görmek de şirki tevhide ulaşmada bir araç olarak görmek anlamına gelmektedir. Diğer taraftan eş-Şankîtî; bazı İslamcıların demokrasiyi, onun felsefesi ve araçları olarak ayırt etmelerine ve destekledikleri kısmın seçimler ve parlamento gibi demokrasinin araçları olduğu görüşüne de itiraz etmektedir. Zira ona göre demokrasiyi, onun Batı menșeli felsefe ve ilkelerinden ayırt etmek mümkün değildir. Dolaysısıyla İslamcıların insanları demokratik sisteme katılıma davet etmesi açık bir şekilde demokrasi ile çatışan 
İslami değerlerin ilgasına yönelik bir davet anlamına gelmektedir (Eş-Şankîtî, 2011, 12-13).

İslamcıların İslamlaşma yolunda "demokrasiye alternatif olacak başka bir sistemin olmadığını" iddia etmelerine de bazı cihâdi düşünürlerden itirazlar gelmiștir. Mesela Ebû Abdurrahman eş-Şankîtî, kaleme aldığı "Tehâfutu'l-Dimukrâtiyyîn" isimli kitapçığında, İslamcıların bu argümanını şaşkınlıkla karşıladığını ifade etmiştir. Zira ona göre ne İslam peygamberi ve ne de onun sahabelerinin uygulamalarında böyle bir metot bulunmaktadır. Öyle ki İslam dininin zafere ulaşması, üç temel rükün olan "ilim, davet ve cihat" ile gerçekleşebilir. Şayet dini gruplar İslam devleti inşa etmeyi arzuluyorsa bu üç yolun dişında bir metot takip etmemelidir. Ona göre demokratik mücadeleyi benimseyenler, fedakârlık gerektiren cihat yolu yerine konforlu ve kolay olanı tercih etmektedirler. Oysa cihat yolu müminlerin üzerine vecibe olan yegâne metottur. Kaldı ki demokrasi gibi dinin haram gördüklerini "alternatif yoksunluğu" delili ile mubahlaştırmaya çalışmak da usul açısından yanlıştır (Eş-Şankîtî, ts., 1516).

Diğer taraftan Ebû Abdurrahman eş-Şankîtî de İslamcıların "siyaset sahasını din düşmanlarına bırakmama" gerekçesine itiraz etmektedir. Ona göre bu bahane ile siyaset arenasına girmek ve laiklerle birlikte aynı meclis çatısı altında bulunmak müesses nizama ve laiklere verdikleri zarardan daha çok fayda sağlayacak, savundukları sisteme meşruiyet kazandıracaktır. Oysa bu sistemden uzak durulur ve toplum da uzak durması için eğitilirse siyasi saha din düşmanlarına bırakılmamış olacak ve hatta onlar bu durumda tam anlamıyla çıkmaz içine girerek kuşatılmış olacaklardır (Eş-Şankîtî, ts., 18-22).

Demokrasinin genelde laiklik ile mündemiç olma zorunluluğu, cihâdî selefi ideologların demokrasiyi sert bir dille eleștirmesinin diğer bir nedeni olmuştur. Mesela İhvan-ı Müslimin'in laik Vefd Partisi ile seçimler için ittifak görüşmeleri sürerken İhvan'ın o dönemdeki mürşidi Ömer et-Tilmisâni'nin laiklik hakkında kendisine sorulan soruya verdiği cevap Eymen ez-Zevâhirî tarafından tenkide tabi tutulmuştur. Öyle ki et-Tilmisâni bu mülakat esnasında laikliğin din karşıtlığı anlamına gelmediğini, aksine dindarlara kendilerini ifade etme özgürlüğü sunduğunu ifade etmiş, ayrıca laik Vefd Partisi'nin diğer partiler gibi İhvan'a zulmetmediğini belirtmiştir. Ez-Zevâhiri ise İhvan'ın İslami hükümler yerine insanların kendilerine nasıl davrandığına bakarak tercihte bulunduğunu belirterek genel mürşide eleştiride bulunmuştur (Ez-Zevâhirî, 2005, 51). Keza dinin parlamento seçimlerine yaklaşımı hakkında kendisine yöneltilen soruya etTilmisânî'nin "dinin bu tür konulara dâhil edilmesini doğru bulmuyorum" şeklinde açıklama yapması da ez-Zevahiri tarafından tenkit edilmiştir. Ona göre etTilmisânî'nin bu açıklaması ile Enver Sedat'ın meşhur "siyasetin içinde dine yer yoktur"1 sözü arasında hiçbir fark bulunmamaktadır. Ayrıca diğer İhvan mensubu entelektüellerin, parlamento seçimlerine iştirak etmenin dinen bir sakıncası olmadığına dair görüşlerini önemli İhvan liderlerinin sözleriyle delillendirmeye çalışmaları da ez-Zevahiri'nin tepkisine neden olmuştur. Ona göre; bu kimseler İhvan mürşitlerinin sözlerini kitap ve sünnetin önüne koymuşlardır (Ez-Zevâhirî, 2005, 55-56).

Bazı cihâdi selefi ideologlar, müesses nizamların kendi sistemlerini meşrulaştırmak adına ana akım İslamcıları nasıl kullandığına sıklıkla vurgu yapmış ve İslamcıların ise bu durumun farkında olmamasından yakınmışlardır. Mesela el-Makdîsîye göre; "tağutî" sistemlerin, İslam davetçilerini tuzağa düşürmek adına başvurdukları 
yöntemlerden biri de kendileri için potansiyel düşman gördükleri komünizm gibi ideolojiler ile mücadelede bazı İslamcıları ve ulemayı kullanıp ön plana çıkarmalarıdır. Ortak düşman olarak görülen bu ideolojilerle mücadele etmeye bu kimseler de gönüllü olur ve durum bir yandan müesses tağuti düzenin sağlamlaşmasına katkı sağlarken diğer yandan da halk nezdinde sistemin meşruiyetinin güçlenmesine neden olur. Böylece bu kimseler bütün enerjilerini tağuta karşı mücadele yerine kendilerine hedef olarak gösterilen ideolojiler uğruna tüketirler. Nihayetinde gün gelir bu kimseler sistemin hizmetçisi ve destekçisi konumuna gelmiş olur. Oysa ona göre; bu ideolojiler Müslümanlara düşman olsalar da asıl olan yakın düşmana karşı savaşmaktır. Zira yakında olan düşmanın tehlikesi, bozgunculuğu ve fitnesi uzakta olan düşmanınkinden daha şiddetlidir (El-Makdîsî, 1984, 66-67).

Diğer taraftan el-Makdîsîye göre müminlere ve davetçilere sistem tarafından bir takım makam, mevki, rütbe, unvan ve imtiyazlar verilmesi onları ayartma açısından çok sık başvurulan taktikler arasındadır. Tüm bu lütufları onları kontrol altında tutabilmek ve ağızlarını kapamak için yaparlar. Böylece "süt emdiğin memeyi ısırmayacaksın" sözü tecelli eder ve söz konusu bu kimseler de fitneye düşene kadar bu ayrıcalıklardan nemalanmaya devam eder ve nihayetinde verdikleri muhtelif fetvalarla sistemin batıl fiillerini onaylamaya başlar (El-Makdîsî, 1984, 67).

Dini radikalizmin bir başka çok önemli ismi olan ve hali hazırda el-Kâide'nin lideri konumunda bulunan Eymen ez-Zevâhirî de İhvan-ı Müslimin'i tenkit ettiği "elHasâdu'l-Murr" isimli kitabında, Ömer et-Tilmisânî, Hamid Ebû'n-Nasır ve Muhammed el-Gazzali gibi İhvan'ın öncü isimlerinin demokrasi, seçimler, siyasal partiler, başkalarının düşüncelerine saygı, hukukun üstünlüğü ve özgürlük gibi demokrasinin temel ilkeleri hakkında ifade ettikleri övücü ve benimseyici beyanatlarından sayfalarca aktarımda bulunarak İhvan-ı Müslimin'in takip ettiği yolun İslami olmadığını göstermeye çalışmıştır (Ez-Zevâhirî, 2005, 48-51).

Ana akım İslami hareketin demokrasi ve mevcut siyasal düzen hakkında benimsediği tutum ve takip ettiği yöntem, her ne kadar dini radikalizm tarafından sert eleștirilere maruz kalmış olsa da ve dini radikal düşünce öncüleri mevcut siyasal sistemin küfrüne hükmetmiş olsa da bu kimseler İslamclları tekfir etme çabası içinde olmamıştır. Nitekim öncü cihâdî ideolog Ebu Mus'ab es-Sûri'ye göre; cihâdî hareket demokrasinin bizzat kendisini din olarak telakki ederken, demokratik sistem içinde kalarak, İslamlaşma için çaba gösteren İslamcıları tevil özründen dolayı tekfir etmemekte, ama söz konusu İslamcıların yaptıkları işe küfür karıştırdığını düşünmektedir (Es-Sûrî, 2004, 1/794).

\section{Din-Hukuk İlişkisi Bağlamında Yöneltilen Tenkitler}

İslam dünyasında teo-politik radikal düşüncenin radikalleșmesine tesir eden en önemli konulardan bir tanesi de hukuk meselesi olmuştur. İkinci Dünya Savaşı'nın akabinde Müslüman topraklar üzerinde kurulan yeni ulus devletler, şüphesiz Batı'da üretilen hukuk sistemlerinden etkilenmişler ve kendi anayasalarını oluştururken bu sistemleri örnek almıştır. Dini radikal grupların; yeni ulus devletleri tekfir etmelerinde ve onlara karşı İslam devrimi ile sonuçlanacağını ümit ettikleri bir savaş içine girmelerindeki temel motivasyonu da söz konusu rejimlerin ülkelerini İslam hukuku yerine modern hukuk ile yönetmeyi tercih etmeleri olmuştur. "Şeriatın tatbiki sorunu" olarak şöhret kazanan problem, altmışlı yıllardan 
günümüze kadar, devlet ile cihâdî gruplar arasında en önemli gerilim kaynaklarından biri olarak var ola gelmiştir.

Cihâdî gruplar bu gerilimi sadece "tağut" olarak isimlendirdikleri müesses rejimlerle yaşamamış, aynı zamanda yine teo-politik bir hareket olan ana akım İslamcılarla da bu konu etrafında anlaşmazlıklar yaşamışlardır. Onlar, başta İhvan-ı Müslimin olmak üzere ana akım İslamcıların, yeni ulus devletlerince oluşturulan anayasaları kabul etmelerini şiddetle eleştirmiştir. Mesela; ana akım İslamcılık düşüncesinden ayrışmanın miladı kabul edilen ellili ve altmışlı yıllardaki hapishane tecrübesi neticesinde Seyyid Kutup'un formülleştirdiği "cahiliye” ve "hâkimiye" teorileri, bir taraftan yeni kurulan Nasır rejimini tanımlamaya yönelik bir çabayken diğer taraftan da zımnen İhvan'ın söz konusu rejime karşı benimsediği tutumun eleştirisi olarak ortaya çıkmıştır. Zira Kutup'un "hâkimiye" düşüncesi, İslam'ın pratik hayatı düzenlemeye yönelik önerdiği hukuki sistemin görmezden gelinmesine bir tepki olarak teşekkül etmiştir. Zira ona göre günümüzde insanların "cahiliye" içinde yaşamaları, Allah'ın, yeryüzündeki otoritesi ve ulûhiyetinin en belirgin özelliklerinden olan "hâkimiyet" $i$ hususunda haddi aşmalarından kaynaklanmaktadır (Kutup, 1979, 8).

Kutup'a göre; günümüzde tüm toplumların "cahiliye toplumu" kapsamına girmesinin nedeni ise onların Allah'tan başkasının ulûhiyetine inanmaları veya ondan gayrısına tapınmaları meselesi değildir. Mesele, söz konusu bu toplumların pratik hayatlarını düzenlerken Allah'a kulluğun gereklerini yerine getirmemesidir. Bu toplumlar her ne kadar Allah'tan başkasını doğrudan doğruya tanrılaștırmamıș olsalar da onlar kanunlarını, yasalarını, ilkelerini, değer yargılarını, adetlerini, geleneklerini ve bütün yaşamsal değerlerini Allah'tan başkasının hâkimiyetine teslim etmektedir. Bu ise ulûhiyetin en belirgin özelliklerinin ihlal edildiği anlamına gelmektedir (Kutup, 1979, 91-92). Ana akım İslamcılık düşüncenin en önemli temsilcisi kabul edilen İhvan-ı Müslimin içinde yetişen Seyyid Kutup'un bu düşünce örgüsü aslında İhvan'ın sahip olduğu teo-politik düşünceye bir tepki olarak da okunmalıdır. Nitekim sonraki yıllarda İhvan genel Mürşidi Hasan el-Hudeybi'nin "Davetçiyiz, Yargılayıcı Değil" isimli kitabını Kutup'un bu düşüncelerine reddiye olarak kaleme aldığı iddia edilmiştir (Zollner, 2009, 65-66).

Keza cihadi hareketin çok önemli öncülerinden biri kabul edilen ve "Kör İmam" olarak bilinen Ömer Abdurrahman'a göre de Kuran'da hâkimiyeti Allah'a isnat etmenin anlamı, kanun ihdas etme yetkisinin yalnızca Allah'a ait olduğunu göstermeye matuftur. Herhangi bir grubun, bir siyasi partinin, halkın veya parlamentonun kanun koyma yetkisi bulunmamaktadır. Beşeriyete düşen Allah'ın ahkâmını tatbik etmek, yeni sorunları çözmek içinse kıyas yolu ile ondan deliller bulup çıkarmaktır. Ona referansta bulunmadan bir șeyi helal veya haram kılmak onun hâkimiyetine savaş açmak ve ulûhiyet konusunda onunla boy ölçüşmek anlamına gelmektedir (Abdurrahman, ts., 28-29). Ömer Abdurrahman'ın hâkimiyet vurgusu da câri siyasal sistem içinde kalarak İslamlaşma yöntemini savunan ana akım İslamcılara dini-hukuki perspektiften yöneltilen bir eleştiri olarak okumak mümkündür.

İslam dünyasında ulus devlet sonrasında neşvünema bulan İslami hareketler içinde tartışmasız bir şekilde dillere en fazla pelesenk olan ve İslamcılar arasında tartışmaya neden olan Kuran ayeti Maide Suresinin 44. ayeti ${ }^{2}$ olmuştur. Bu ayet etrafında ayetin gerçek maksadının ne olduğu üzerine tartışmalar mütemadiyen devam etmiştir. Ana akım İslamcılar, ayetin nüzul bağlamını önemsemenin 
gerekliliği üzerine vurgu yapmış ve ayetin özel olarak Yahudilerle alakalı olduğunu iddia etmiştir. Dolayısıyla Müslüman ülkelerdeki devlet yöneticilerinin, bu ayeti referans alarak tekfir edilemeyeceğini savunmuşlardır. Ömer Abdurrahman ise esasında mahkeme savunması olan ve daha sonra kitaplaştırılan "Kelimetu Hakk" isimli eserinde bu ayeti uzun uzadıya açıklamaya çalışmıştır.

Ona göre bir Müslüman, Allah'ın teşri ettiği hükmün dışında bir hüküm ihdas eder ve Kuran'ın ortaya koyduğu ceza hukukunu uygulamazsa küfre girmiş olur. Zira Allah'ın koyduğu cezayı bırakıp yerine bașka bir ceza hükmünü uygulamak İslam'dan yüz çevirmek anlamına gelmektedir (Abdurrahman, ts., 55-56). Dolayısıyla Allah'ın şeriatına muhalif olacak şekilde beşerî kanunlara uyanların küfre ve şirke düștükleri hususunda herhangi bir şüphe bulunmamaktadır. Öyle ki mirasta erkeğin kadından fazla pay almasını insafsızlık olarak görüp kadın ve erkeğin eşit olmalarını gerektiğini söyleyerek veya çok eşliliğin ve boşanmanın kadına zulüm olduğunu düşünerek veya recm ve hırsızlık cezalarının vahşice bir muamele olduğunu kabul ederek yeni bir hukuk düzeni oluşturmak yaratıcının inkârı anlamına gelmektedir (Abdurrahman, ts., 62). Yine faizin serbest bırakılması, içki, zina ve hırsızlık gibi suçlara İslam ceza hukukunun uygulanmaması gibi Kuran ve Sünnete açıkça muhalif olan bir anlayışı sürdürmek ve kâfir devletler tarafından üretilmiş ithal kanunları İslam diyarında tatbik etmek ve bu kanunlara rıza gösterip başvurmak küfürdür (Abdurrahman, ts., 64).

Diğer taraftan yöneticiye (ulu'l-emr) itaati salık veren Maide Süresi 50. ayeti ${ }^{3}$ de radikal gruplarla diğer İslami gruplar arasında teo-politik bağlamda tartışma konusu olan ana temalardan biri olmuştur. Bașta geleneksel selefiler olmak üzere ana akım İslamcılar da dâhil pek çok İslami grup, silahlı mücadele yoluyla İslami devrim amacı güden dini radikal düşüncenin doğru yolda olmadığını bu ayete referansta bulunarak sıklıkla dile getirmiştir. Ömer Abdurrahman ise hem bu ayeti ve hem de Buhari ve Müslim'de geçen; "Sizden kim emirinden kerih bir şey görürse buna sabretsin, kim cemaatten bir karış dahi uzaklaşır ve ölürse cahiliye üzerine ölmüş olur" hadisini kendilerine karşı delil olarak kullananlara itirazını dile getirmiştir.

Ömer Abdurrahman; ayeti yorumlarken ayetteki “...sizden olan emir sahiplerine...” kısmının altını çizmektedir. Ona göre; "bizden" olan emir sahibinin anlamı, tıpkı bizim gibi Allah ve resulüne itaat eden ve Allah'ın şeriatına bağlı olan iktidar sahipleri demektir. Buna göre ulu'l-emrin (yöneticinin) mutlaka iman, istikamet ve takva üzerine olması gerekir (Abdurrahman, ts., 30-31). Ona göre; şayet devlet başkanı zalim, fasık ve Allah'a karşı asi olduğu taktirde ona karşı çıkmak gerekmektedir. İtaat hususunda mutlaklık söz konusu değildir. Bir devlet başkanı dine, Irza ve vatana ihanet ediyorsa ona isyan etmek gerekir. Bu görüşü savundukları için kendilerine Harici denmesine de itiraz etmektedir. Öyle ki ona göre; kendileri bu görüşü savundukları için Harici oluyorsa, 1952 Hür Subaylar devrimini yapıp bugünkü sistemi kuranların ve onu destekleyenlerin (İhvan'ı Müslimin kastedilmektedir) de Harici olması gerekmektedir. Zira kendisine isyan edilen ve yönetimden düşürülen Kral Faruk da kelime-i şehadet getiren, cuma ve bayram namazlarına giden bir liderdi (Abdurrahman, ts., 136-138).

Diğer taraftan Ömer Abdurrahman, İslami hareketin şeriat talepleri karşısında özellikle yönetici konumundaki kimselerin şeriatı uygulamama gerekçelerine de itiraz etmektedir. Bazı kimseler Ömer Abdurrahman'a, şeriatın tatbiki hususunda 
hali hazırda şartların uygunsuzluğundan, karışıklığa ve huzursuzluğa yol açacağından, halkın rıza göstermeyeceğinden ve dış tehditlerden bahsetmektedirler. Ömer Abdurrahman'a göre bu şekilde mazeret ileri sürenler, Allah'ın tüm zamanları kapsayan ilminden şüphe duymaktalar veya Allah'ın ortaya koyduğu şeriatın yeni olgular karşısında aciz kaldığını varsaymaktadırlar (Abdurrahman, ts., 71-72).

Diğer taraftan bu minvalde Eymen ez-Zevâhiri de Hasan el-Benna ve Salih 'İșmâvî gibi İhvan'ın öncü isimlerinin 1923 Mısır Anayasası hakkında övücü sözlerini aktardıktan sonra anayasada İslam'la çeliştiğini düşündüğü maddeleri tek tek sayarak Kuran'dan ayetler getirmek suretiyle İhvan'ın anayasa karşısındaki tutumunun gayri İslami olduğunu göstermeye çalışmıştır (Ez-Zevâhirî, 2005, 45-46; 51-53). Yine ez-Zevâhiri, eski mürşitlerden Ömer et-Tilmisânî'nin modern hukukun İhvan hareketi nezdinde bağlayıcı olduğunu deklare etmesini de tenkide tabi tutmuş, özellikle hadislerden örnekler getirerek İslami olmadığını göstermeye çalışmıştır (Ez-Zevâhirî, 2005, 53-54).

Ayrıca ana akım İslamcıların bağlayıcılığını kabullenmeyi deklare ettikleri modern hukukun inanç özgürlüğü ve düşünce özgürlüğü gibi kişisel özgürlükler alanında sağladığı esneklik, radikal gruplarca modern hukukun kabul edilemez olduğunun gerekçesi olarak da sunulmuştur. Zira söz konusu bu esneklik toplum içinde her türlü fuhşiyatın ve İslam dışı propagandanın kişisel özgürlükler adı altında yayılmasına yol açmaktadır. Dini radikal gruplara göre; eşcinselliğe kadar varacak bu tür esnekliklerin ana akım İslamcılar tarafından dikkate alınmaması kabul edilemezdir (El-Lecnetu'ş-Şer'iyye, ts., 78-81).

El-Makdîsî'nin iddiasına göre de birçok "tağuti" sistem parlamento ve meclis gibi resmi kurumların kapılarını davetçilere açmak suretiyle onları sistemin içine çekme çabası içinde olmuştur. Hasımları ile aynı çatı altında toplanan davetçiler, yaptıkları sonu gelmez toplantılar neticesinde benimsedikleri davanın düşmanları tarafından sulandırıldığını bir müddet sonra idrak edemez hale gelirler. Nihayetinde esas davaları olan kâfirlerden uzak durma, onların kanunlarını kabul etmeme ve onların takip ettiği yolu tanımama gibi meseleleri bir kenara bırakıp vatanın ve milletin selameti, güvenliği ve ekonomik kalkınması gibi meseleleri dert edinmeye başlarlar. Tüm bu çaba küfürle yönetilen vatanlar için verilmektedir. Davetçiler bu tuzağa düştükten sonra artık düzenin neferi haline dönüşürler ve kanunlara ve anayasaya bağlı kalacaklarına dair yeminler etmeye başlarlar (El-Makdîsî, 1984, 66).

\section{3.İslamlaşma Yöntemi Sorunsalı ve Ötekiyle Olan İlişki Bağlamında Yöneltilen Tenkitler}

Günümüzde cihâdî selefilik olarak tanımlanan teo-politik radikal düşünce ve hareket ilk olarak altmışlı yıllarda Mısır'da oluşmaya başlamıștır. Cemal Abdunnasır'ın kendilerine yönelik sert baskı politikası ile yüzleşen ana akım İslami hareket müntesipleri arasında bu baskıya nasıl mukabele edilmesi gerektiği hususunda yaşanan fikrî ihtilaf, dini radikal düşüncenin ilk nüvelerini oluşturmuştur. Bu fikrî ihtilafın çıkış noktası ise söz konusu yeni ulus devlet rejimine karşı mücadelede benimsenmesi gereken yöntem sorunudur. Ana akım İslami hareketin lider kadrosu; söz konusu baskı karşısında galeyana gelmemeyi salık vermiş, teenni ile hareket edilmesini önermiş ve İslamlaşma yolunda davet ve irşat faaliyetlerine odaklanıp uzun vadeli dönüşümün amaçlanmasını savunmuştur. 
O dönemde İslami hareketin içinde bulunan ve daha çok hapishanedeki gençlerden oluşan bir kesim ise ana akımın bu teklifine itirazda bulunmuș, muhatap oldukları sert muameleye karşı aynı sertlikle cevap vermeyi önermiş, İslamlaşmanın tedrici bir yolla değil de ancak silahlı mücadele yoluyla mümkün olabileceğini savunmaya başlamıştır. Öyle ki altmışlı yıllardan günümüze kadar İslamlaşmanın gerçekleşmesi için takip edilmesi gereken yöntem (menhec) hususu, dini radikalizmin ana akım İslamcılara yönelttiği tenkitler arasında merkezî bir yer almaktadır. (Es-Sibâ'î, 2006) Kaldı ki İslamlaşma yöntemi meselesi etrafında modern dönemde tebarüz eden ihtilaf sadece dini radikal düşünce ile ana akım İslamcılar arasında tecrübe edilen ayrışmayla sınırlı kalmamış, geleneksel selefi gruplardan sûfi gruplara, modern dini cultlardan geleneksel tarikatlara kadar bütün dini grup ve yapıları içine alan temel bir ayrışma sorunsalı olarak tebellür etmiştir. Dini radikal gruplara yön veren ideologlar da aslında bu mesele etrafındaki tenkitlerini sadece ana akım İslamcılara yöneltmemiş, diğer dini akım ve gruplar da bu eleștirilerden nasibini almıştır. ${ }^{4}$ Fakat biz araştırmamızın kapsamı gereğince bu başlık altında radikal gruplar tarafından İhvan-ı Müslimin hareketi bașta olmak üzere ana akım İslamcılara yöntem (menhec) sorunu etrafında yöneltilen tenkitleri incelemeye tabi tutacağız.

Mesela bu minvalde Eymen ez-Zevâhiri, İhvan'ın kurucu ismi Hasan el-Benna'nın şiddet karşıtı sözlerini ve onun takip edilmesi gereken yöntem hususunda ortaya koyduğu şiddet karşıtı duruşu uzun uzadıya kritiğe tabi tutmuştur. Ez-Zevâhiri'nin aktarmasıyla Hasan el-Benna; kötülük (münker) olarak kabul edilen meselelerde, kötülüğün ortadan kaldırılması hususunda bireylerin ferdi olarak inisiyatif alamayacağını belirtmiş, ${ }^{5}$ bu görevi hükümetlerin icra etmesi gerektiğini, aksi taktirde toplumda kaos ortamının oluşacağını ifade etmiş̧tir. Benna'ya göre; İslam'ın münker olarak kabul ettiği meselelerin kanun ve nizam çerçevesinde değişebilmesi için de bu konulara duyarlı Müslüman temsilcilerin parlamento içinde bulunması gerekir.

Ez-Zevâhiri, kötülüğün önlenmesine yönelik görevin hükümetlere ait olduğuna dair Hasan el-Benna'nın görüşüne itiraz etmektedir. Ona göre; “iyiliğin emredilip kötülüğün yasaklanması"6 farz-ı kifâye hükmünde bir vecibedir. Şayet siyasi otorite dinin münker gördügü hususları ortadan kaldırma konusunda harekete geçmezse bu görev, gücü yetebilen her bir ferdin sorumluluğuna geçmiş olur. Ayrıca ezZevâhiri, münkerin ortadan kaldırılması görevini meclis çatısı altındaki dindar temsilcilere hasreden Hasan el-Bennâ'yı bazı hakikatleri görmezden gelmekle suçlamaktadır. Öyle ki ez-Zevâhiri'ye göre bizzat parlamento seçimleri laik anayasal düzenin kontrolü altında gerçekleşmektedir. Dolayısıyla seçimlere katılmak da bu laik anayasal düzenin meşru olduğunu kabullenmek anlamına gelmektedir. Diğer taraftan Mısır'ın o dönemde içinde bulunduğu fesadın asıl nedeni müesses laik rejimdir ki onları kontrol eden İngiliz sömürüsü zaten İslami değişim talebine izin vermeyecektir. Ez-Zevâhiri'ye göre, İhvan lideri bu hakikatleri görmezden gelmektedir. Ona göre; zaten İhvan hiçbir vakit sağlam akidevî temeller üzerine dayanan bir ıslah yolunu takip etmemiş ve her daim açık seçik görünür olan çürümeyi görmezden gelerek onun üstünü örtmeye çalışmıștır. En başında Kral Faruk'a biat ederek bu karanlık tünelin içine giren İhvan, Hüsnü Mübarek dönemine dek bu tünelden çıkamamıştır. Oysa olması gereken İhvan'ın yaptığı gibi haklar ve özgürlükler ekseninde basit İslami taleplerde bulunmak değil, İslam düşmanı harici 
güçlere tabi olan laik sistem içinde kalmamak, onlardan beri olmak ve onlara karşı cihat etmektir (Ez-Zevâhirî, 2005, 55-59).

Ayrıca ez-Zevâhiri; Hasan el-Benna dıșında Hasan el-Hudeybi, Ömer et-Tilmisânî, Muhammed Hamid Ebû Nasır ve Ferid Abdulhalık gibi İhvan hareketinin öncü isimlerinin İslamlaşma adına takip edilmesi gereken yöntem hususunda şiddet karşıtlığına, davet ve irşat gibi barışçıl yollara vurgu yaptıkları cümleleri alıntılamış ve onların hukukiliğe ve meşru zemine önem veren ifadelerini eleştiriye tabi tutmuştur. Özellikle İhvan'ın üçüncü mürşidi Ömer et-Tilmisânî ile dördüncü lideri Hamid Ebu Nasır'ın şeriatın tatbiki konusunda aceleci davranmayacakları, tedrici bir yolu benimseyecekleri ve teenni ile hareket edeceklerine dair çeşitli vesilelerle yaptığı açıklamalar, ez-Zevâhiri'nin eleștirilerinin yoğunlaştığı noktalar olmuștur (Ez-Zevâhirî, 2005, 59-71).

On dokuzuncu yüzyıldan günümüze kadar İslamcılık düşüncesinde ve ana akım İslami harekette, cihat ameliyesinin muhatabı çoğu zaman sömürgeci Gayrimüslim unsurlar veya Filistin topraklarını işgal eden İsrail olmuştur. Ana akım İslami hareketin bir sapması olarak teșekkül eden cihâdî selefi terminolojide ise bu tasavvur "uzak düşman" olarak kavramsallașmıștır. Bunun mukabili olan "yakın düşman" ise Müslüman ülkelerdeki müesses rejimleri tanımlamak için kullanılmıștır. Fakat "yakın düşman"a karşı cihat ameliyesinde bulunma fikri ana akım İslami hareket ile dini radikal düşünce arasındaki temel anlaşmazlık konularından bir tanesi olmuştur. Yukarıda da ifade ettiğimiz gibi ana akım İslami hareket Müslüman ülkelerdeki rejimlere karşı silahlı mücadeleyi onaylamazken cihâdî hareket ise devrim yoluyla rejim değişikliği gerçekleştirmenin gerekliliğini savunmuştur. Ez-Zevahiri de kitabında İhvan'ın cihat anlayıșının "uzak düşman” ile sınırlı kalmasını da tenkide tabi tutmuştur. Özellikle o, İhvan'ın ilk kuruluş aşamasında İngiliz karşıtlığı ve sonraki yıllarda da Filistin meselesi ile münhasır kalan, hiçbir şekilde müesses rejime ve onun unsurlarına yönelmeyen cihat perspektifinden şikâyet etmiştir (Ez-Zevâhirî, 2005, 73-74).

Ez-Zevâhiri; İhvan'ı sıkı eleștiriye tabi tuttuğu "el-Hasâdu'l-Murr" adlı kitabının büyük bir bölümünde, Müslüman Kardeşler hareketinin kuruluşundan itibaren geçen süre içerisinde iktidarla olan ilişkisinin müesses nizamın meşruiyetini güçlendirmekten başka bir işleve sahip olmadığını iddia etmiştir. 0, Kral Fuad'tan ${ }^{7}$ Cemal Abdunnasır'a, ${ }^{8}$ Enver Sedat'tan ${ }^{9}$ Hüsnü Mübarek'e ${ }^{10}$ kadar İhvan'ın iktidarla olan ilişkisini ele almış ve İhvan'ın öncü isimlerinin bu kimseler hakkındaki açıklamalarını uzun uzadıya aktararak kritik etmiştir. Ez-Zevâhiri'ye göre İhvan'ın bu süreçte iktidar ile olan ilişkisinin dayanağı pragmatizm olmuştur. Müslüman Kardeşler hareketi her daim kendi örgütsel maslahatlarını İslam davasının önüne koymuştur. Özellikle Hüsnü Mübarek döneminde çeşitli siyasi parti, grup ve kişilerle $^{11}$ iş birliği içine girmeleri de statükonun daha fazla tahkim edilmesine katkı sağlamıştır.

Diğer bir önemli eleştiri konusu da tekfir hususunda ana akım İslamcılığın benimsediği yol üzerine olmuştur. Özellikle İhvan; Cemal Abdunnasır döneminde İslamcı gruplar arasında yeni ulus rejimin tanımlanması hususunda yaşanan tartışmalarda tekfiri kesinkes reddeden bir çizgide durmuştur. İlk bölümde de temas ettiğimiz gibi II. Murşid Hasan el-Hudeybi tarafından Seyyit Kutup'un "Yoldaki Issaretler" kitabına bir reddiye olarak kaleme alındığı iddia edilen "Davetçiyiz, Yargılayıcı Değil” isimli eserin başlığı bile İhvan'ın kuruluşundan günümüze tekfir konusundaki tutumunun dile yansıyan en veciz hali olarak dikkat çekmektedir. 
İhvan'ın bu tutumu ise her daim radikal grupların kendilerine yönelttiği önemli tenkit maddelerinden biri olmuştur.

Dini radikalizmin önemli metinlerinde ana akım İslamcılık, tekfir konusunda Kuran ve Sünnetin açlk beyanına mugayir tutum benimsemekle itham edilmiştir. Bu metinlere göre; naslardaki bu açık seçik beyanlara mugayir hareket eden İslamcılar ya cehaletle hareket etmektedirler ki bu durumda insanlara fikir beyan etmeleri caiz değildir, ya nasları reddeden sapkınlık içindedirler ya da imanı amelden bağımsız sadece tasdik ve ikrar olarak görmekte ve böylece onlara göre sapkın bir yol olan Mürcie mezhebinin düștüğü hataya gark olmaktadır (El-Lecnetu'ş-Şer'iyye, ts., 3435).

Yukarıda da değindiğimiz gibi İslam dünyasında dini radikalizm kendi ötekisini "yakın düşman" ve "uzak düşman" olarak iki kategori altında tanımlamıştır. Söz konusu bu düşman gruplarıyla ne tür bir ilişki içinde olunacağ meselesinde ise temel ilke olarak, Vehhabi düşünceden mülhem, "el-Velâ' ve'l-Berâ'” prensipleri ana zemin olarak kabul edilmiştir. Öteki ile girişilen münasebetin mahiyeti, dini radikal gruplarla ana akım İslamcılar arasındaki gerilimi tetikleyen temel unsurlardan biri olmuş ve bu mesele dini radikalizmin İslamcılara yönelttiği önemli tenkit temaları arasında yer alan başka bir husus olmuştur.

İhvan-ı Müslimin başta olmak üzere ana akım İslamcılar, İslamlaşma yolunda fevri davranıp bu mecrada yapılan hizmetlerin sekteye uğramaması ve İslami hareketin maslahatına zeval gelmemesi için özen gösterilmesi gerektiğini düşünmüşler ve yukarıda da ifade ettiğimiz gibi Müslüman toplumların ve devlet idaresinin İslamlaşması için tedrici ve yer yer gizliliği esas alan bir yolun benimsenmesini salık vermişlerdir. Onların bu tutumları dini radikal öncüler tarafından el-Velâ' ve'l-Berâ' bağlamında da tenkite tabi tutulmuștur.

Şüphesiz öteki ile olan ilişkinin mahiyeti etrafında en fazla kalem oynatan kişi olarak Ebû Muhammed el-Makdisi dikkat çekmektedir. 0, ana akım İslamcıların, özellikle "yakın düşman" ile olan ilişkilerinde söz konusu ihtiyatlı tutumunu sert bir üslupla eleştirmiştir. El-Makdîsî; günümüzde Müslümanların takip etmesi gereken yolu, (menhec) Kuran'da geçen "Millet-i İbrahim" tabirinden ilham alarak İbrahim Milleti olarak isimlendirmiş ve bu isimle bir kitap telif etmiştir. 0, İbrahim Milleti'nin niteliklerini zikrettiği bu kitabında Mumtehine Suresi'nin 4. ayetindeki ${ }^{12} \mathrm{~Hz}$. İbrahim'in kavmine karşı hitap tarzından ilham alarak İslamlaşma yolunda aleniliğin Kurani bir metot olduğunu göstermeye çalışmıştır.

$\mathrm{Bu}$ ayetin tefsiri için geleneksel selefi ulemanın görüşlerine başvuran el-Makdîsî, düşmana karşı düşmanlığın ana akım İslamcıların yaptığı gibi gizli ve tedrici bir yolla değil aleni bir şekilde yerine getirilmesinin gerekli olduğu sonucuna ulaşmıștır. Düşmanlık; aşikâr, açık ve net olmak zorundadır. Aksi takdirde bu gereklilik yerine getirilmemiş olur. Zira buğz etmek sadece kalpte kalır, düşmanlık ve ilişkiyi kesme gibi belirtiler açığa vurulmazsa salt içeride öfke beslemenin bir fayda sağlayacağ düşünülmemelidir. Dolayısıyla bir Müslümanın yapması gereken; Allah'ın düşman olarak tanımladığı kimselere düşmanlık beslemesi, bu düşmanlığı aşikâr etmesi, onlara tam anlamıyla mesafe koyması, onlarla dostluk ve yakınlık kurmaması, içli dışlı olmaması, onlardan nefret etmesi ve onlara karşı cihat etmesidir (El-Makdîsî, 1984, 18-22). 
Günümüzde diyor el-Makdîsî, beşerî kanunlar ve anayasalar üzerinde şirkin tahakkümünün ne kadar yaygın hale geldiği aşikârdır. Dolayısıyla davetçilerin, İbrahim Milleti'ne tabi olan Nebi'yi örnek alarak bu kanun ve yasaları küçümsemeleri, bunların eksikliklerini insanlara hatırlatmaları, bu yasa ve kanunları açıkça inkâr edip onlara karşı olan düşmanlıklarını deklare etmeleri ve insanları da bu tutuma davet etmeleri gerekmektedir. Nasıl Hz. İbrahim tereddütsüz bir şekilde putları kırmış, Hz. Muhammed de hakikati haykırmışsa günümüz Müslümanları da zayıf oldukları bir dönemde dahi olsalar istenileni söylemekten imtina etmemeleri gerekir. Hz. İbrahim'in kırdığı put, herhangi bir yerde ve zamanda değişik formlarıyla ortaya çıkan bir heykel veya bir kabir, bir tağut veya bir sistem olabilir. Bununla kastedilen ise, tağuta karşı izhar edilmesi gereken buğz ve düşmanlığın en yüce mertebesi olan cihat ve savaştır. Şayet bu şekilde bir yöntem benimsenmezse hakikatin ortaya çıkması, insanların dinlerini gerçek anlamda öğrenmeleri, doğruyu yanlıştan ve dostu düşmandan ayırt etmeleri mümkün olmayacaktır (El-Makdîsî, 1984, 23,47). El-Makdîsî’ye göre; toplumun ve devletin İslamlașması yolunda tek doğru ve takip edilmeyi hak eden yöntem söz konusu Millet-i İbrahim yöntemidir (El-Makdîsî, 1984, 33).

El-Makdîsî, kendilerinin takip ettiği söz konusu bu metodun bazı kimselerce İslam davetinin maslahatına halel getirmesi ve fitneye sebep olması düşüncesiyle eleştirilmesinden de yakınmaktadır. Ona göre; tevhidin hakiki anlamını gizlemek ve insanlar için anlaşılması noktasında dinlerini daha çetrefilli hale getirmek daha büyük bir fitnedir. Yine Müslüman için, İbrahim Milletini ikame etmekten, Allah'ın dinine dost olanları dost ve tağutu da düşman olarak ilan etmekten daha büyük bir maslahat bulunmamaktadır. Dolayısıyla bu temel mesele için Müslümanların sıkıntıya uğraması ve bunun için fedakârlıkta bulunması tabidir. Zira kelime-i şehadetin ilk yarısı mucibince tüm tağutları aleni bir şekilde inkâr etmek, tüm Müslümanlar üzerine vaciptir (El-Makdîsî, 1988, 137; a.mlf, 1984, 23).

Özellikle el-Makdîsînnin benimsediği "davette alenilik" metoduna karşı ciddi eleştirilerin geldiği anlaşılmaktadır. Kitabında bu eleştirileri zikreden el-Makdîsî, bu eleștirilere cevaplar vermeye çalışmıştır. Bu eleștirilerden biri, el-Makdîsî ve onun yolunda gidenlerin davet yönteminde benimsedikleri aleniliğin, İslami hareket müntesiplerini ve onların planlarını deşifre etmesine, davetin ve onun meyvelerinin yok olmasına sebebiyet verme ihtimalini taşımasıdır. Nitekim bu kimseler İslam peygamberinin de gizlilik prensibini benimsediğini iddia etmiştir. El-Makdîsî bu eleştirilere itiraz etmiş ve peygamberin gizlilik prensibini tağutları, onların sistemlerini ve batıl ilahlarını eleştirme noktasında uygulamamış, daha çok savaş hazırlığında ve planlama yaparken bu prensibe bağlı kaldığını ifade etmiștir. 0 , davet ve tebliğde, hakikati söylemede gizli davranmayıp açıç̧a doğru olanı ilan etmiş ve "sizin dininiz size, benim dinim de bana" diyebilmiştir. Ona göre bu yöntem benimsenmediği sürece bazı kimselerin üzerine titrediği davetin semereleri hiçbir zaman olgunlaşmayacaktır. Hatta günümüzde gençlerin İslam konusunda cahil kalmalarının yegâne nedeni, söz konusu bu ulemanın hakikati açıkça söyleyememiş olmalasıdır. Âlim takiyye yaptığı takdirde hakikatin zuhur etmesi mümkün değildir (El-Makdîsî, 1984, 31-32).

Yine bazı İslami hareket müntesiplerinin davet metodu olarak Kuran'daki yumuşak olma, nazik davranma ve kolaylaştırma ile ilgili nasları dini radikalizm metodunu eleștirme sadedinde sürekli gündemde tutmaları el-Makdîsî’yi rahatsız etmektedir. ${ }^{13}$ Ona göre; bu kimseler söz konusu nasları yerli yerinde 
kullanmamakta, davet hususunda samimi davranmamakta ve bu konuyu tam manasıyla kavrayamamaktadır. El-Makdîsî’ye göre; söz konusu naslar davete ilk defa muhatap olan kimse için söz konusu olup bu yaklaşım tarzı başarısız olduktan sonra davetin üslubu da değişmek zorundadır. Oysa ona göre; günümüzdeki "tağuti" rejimler, her geçen gün insanların arasında küfrün ve bozgunculuğun artmasına ses çlkarmamakta ve hatta bunu tasdik etmektedir. Üstelik toplumu islah etmek isteyen davetçilere karşı baskı kurmakta ve onları istihbarat ve polis servisleriyle sürekli gözetim altında tutmaktadır. Yine onların beşer ürünü, şirk mahsulü yasalarına itiraz eden, onu inkâr edip ondan uzak (berî̀) olduğunu deklare eden ve insanlara bu yasaların batıl olduğunu anlatan herkesi cezalandıracak kanun ve kararnameler çıkarmaktadırlar. Buna mukabil Allah'ın dinine savaş açan her bir kimseye de alan açmakta ve küfür ve fesatlarını yaymak için basın yayın organlarını onların hizmetine sunmaktadırlar. İște bu gibi kimselere karşı yumuşak üslup benimsemek, onlara güzel sözler söylemek ve onlara ve düzenlerine dostluk göstermek caiz değildir. Hz. İbrahim'in yaptığı gibi onlardan ve işledikleri fiillerden berî' olunduğunu deklare etmek gerekir. Keza onları dost edinmekten, onların boyunduruğu altına girmekten ve askerlik ve polislik gibi onların düzenlerini tahkim etmeye katkı sağlayacak bütün vazifelerden uzak durmak gerekmektedir (El-Makdîsî, 1984, 27).

Ebu Muhammed el-Makdîsî'nin hareket metodunda aleniliğe aşırı vurgu yapması aslında ana akım İslami hareketlere karşı açık bir tenkit olarak okunmalıdır. Zira gerek davet ve irşat faaliyetlerini merkeze alan cemaatlerin ve gerekse de cari sistemin çerçevesini çizdiği politik arenanın içinde kalarak toplumun ve devletin İslamlaşması için mücadele eden muhtelif grupların, hareket metodu olarak tedriciliği, maslahatı ve yer yer de gizliliği esas alması el-Makdîsî̀ye göre, kendisinin İbrahim Milleti yolu olarak isimlendirdiği aleniliği savunan Kuranî metoda mugayirdir.

Diğer taraftan El-Makdîsî, "bera'” ilkesi gereğince zulme ve küfür kanunlarına destek niteliğinde olan her türlü resmi vazifeden de uzak durulması gerektiği fikrini benimsemiștir. Ona göre muvahhit bir Müslümanın, küfrün ve batılın korunması anlamına gelen emniyet teşkilatında veya ordusunda, istihbarat biriminde, danışmanlık hizmetlerinde, vergi, gümrük ve hazine gibi iktisadi alanlarda, tağutun temsilciliği olan konsolosluk ve elçilik görevlerinde, savcılık, avukatlık ve hâkimlik gibi yargı sahasında, parlamento üyeliği ve bakanlık gibi vazifelerde görev alması düşünülemez. Zira bu vazifelerin üstlenilmesi, tağuti sisteme tabi olmak, icraatını onaylamak ve kanunlarını içselleştirmek anlamına gelmektedir. Bütün bunların yanında el-Makdîsî, tağuti müesses nizamın şiarlarından olan bayrak gibi sembollere sevgi beslemeyi, onları asmayı ve yaymayı da bu sisteme boyun eğmek ve onu dost edinmek olarak görmektedir ${ }^{14}$ (El-Makdîsî, 1988, 106-129).

Bazı kimseler el-Makdîsî’nin önerdiği metodu, İslam peygamberinin takip ettiği yola uymadığı için eleştirmişlerdir. Öyle ki peygamber, Mekke döneminde putların arasında on üç yıl boyunca yaşamış, zayıf olduğu bu dönemde putları kırmaya yeltenmemiştir. El-Makdîsî, bu görüşü ileri sürerek kendisine itiraz edenleri İslam dinini bilmemekle suçlamıștır. Ona göre; peygamberin on üç yıl boyunca kavmi arasında yaşaması günümüzde bazı davetçilerin yaptığı gibi tağuti yasalara karşı övgüyle bahsetmesi ve onlara saygı göstermesi anlamına gelmemektedir. Bilakis peygamber, kendisinin ve arkadaşlarının tağutun işlerinden ve ilahlarından berî̀ olduğunu açıkça ilan etmiştir. Oysa günümüzdeki davetçilerin çoğunluğu batıl ehline 
karşı dalkavukluk yapmakta, onlara yumuşak davranmakta ve hatta onlara destek olup yardım etmektedirler. Artık mesele öyle bir hal almıştır ki, düşmanlık ve buğzun yerini vatanın ve milletin selameti için omuz omuza iş birliği almıştır (ElMakdîsî, 1988, 137-138; a.mlf, 1984, 47-49).

Dini radikalizm; ana akım İslamcıları, din ile modern olan arasında sıkışıp kalmakla itham etmiş, onların sürekli bir kafa karışıklığı ile malul olduklarını iddia etmiştir. İhvan'ın pek çok meselede muğlak ve ikircikli (bize göre pragmatist) bir tutum sergilemesi çok sık eleştirilen mesele olarak dikkat çekmektedir. ${ }^{15}$ Dini radikalizm; İhvan özelinde yine ana akım İslamcıları, çoğulculuk, ötekine saygı ve düşünce özgürlügü gibi konularda hâkim batılı paradigmaya teslim olmakla ve dinin bu konulardaki öğretilerini dikkate almamakla suçlamaktadır. İhvan'ın Mısır'daki Gayrimüslimlere yaklaşımının vatandaşlık hakları çerçevesinde olması, bu tutumunu vatan kardeşliği olarak tanımlanması da İhvan'ın el-velâ ve'l-berâ bağlamında eleştirilmesine neden olmuştur (El-Lecnetu'ş-Şer'iyye, ts., 36-44).

Son olarak öncü cihâdî ideolog Ebû Basîr et-Tartûsî ana akım İslami hareketin takip ettiği yöntemin başarısız olduğunu iddia etmiş ve başarısızlığının kanıtı olarak da ana akım İslamcıların, geçen yetmiş yıllık süre içinde İslami bir yönetim kurma ve Müslüman toplumun sorunlarına çözüm üretebilme gibi pek çok konuda hedeflerine ulaşma hususunda hiçbir kazanım elde edememelerini göstermiş ve sürekli yerlerinde sayarak kendilerini tekrarladıklarını ifade etmiştir (Et-Tartûsî, 2005, 1$3)$.

\section{Sonuç}

$\mathrm{Bu}$ araștırmamız, ana akım İslami hareketin bir sapması olarak altmışlı yıllarda filizlenen, yetmiş ve seksenli yıllarda olgunlașan ve doksanlı yıllardan sonra ulus ötesi bir hüviyet kazanıp sürekli dönüşüm geçiren dini radikal düşüncenin, İhvan-ı Müslimin başta olmak üzere ana akım İslamcılık düşüncesine ve İslamcılarına yönelttiği tenkitleri incelemiştir. Her iki ekolün İslam dünyasını ve Müslüman toplumu ilgilendiren konularda siyasal hassasiyete sahip olması ve bu hassasiyetin onlara aksiyon kazandırması, bu iki ekolün zaman zaman "siyasal İslam" tanımlaması altında aynı kategoriye dâhil edilmesine neden olabilmiştir. Bu çalışmanın temel amacı, dini radikalizmin birincil metinlerini incelemek suretiyle her iki ekolün pek çok meselede tam bir karşıtlık içinde olduğunu dini radikalizmin ana akım İslamcılara yönelttiği tenkitler üzerinden göstermeye çalışmaktır.

Dini radikalizmin ana akım İslami harekete yönelttiği eleştiri temalarını üç ana başlık altında inceledik. Her iki ekole dinamizm kazandıran ve onları motive eden bir unsur olarak teo-politik hassasiyetin gerek ana akım İslamcılığın ve gerekse de dini radikal düşüncenin ortak paydası olması hasebiyle ilk olarak "din-siyaset ilişkisi bağlamında" yöneltilen tenkitleri incelemeye tabi tuttuk. Bu inceleme sonucunda ana akım İslami hareketin cari siyasal düzen içinde barışçll bir yolla yer alma çabasının radikal gruplarca en fazla tenkide maruz bırakıldığı mesele olduğunu fark ettik. Bu bağlamda ana akım İslami hareketin demokrasiyi, demokratik değerleri ve kurumları kabul eden ve onu içselleştirdiğini deklare eden tutumu ve İslamlaşmanın mevcut siyasal düzen içinde erk sahibi olmakla mümkün olabileceğini savunan iddiası dini radikal ideologlar tarafından din-siyaset ilişkisi bağlamında en fazla tenkit edilen temalar olduğunu mülahaza ettik. Pek çok cihadî ideolog kaleme aldıkları metinlerde, temel dini kaynaklardan ve geleneksel ulemadan referansta 
bulunarak İslamcıların, mevcut siyasal değerler ve düzen ile olan ilişkisini sert bir üslupla tenkide tabi tuttuğunu göstermeye çalıştık.

Bağımsızlık sonrası dönemde; İslam dünyasında kurulan yeni ulus devletlerin anayasalarını oluştururken, Batı'da üretilen hukuk sistemlerini kendilerine örnek almaları, dini radikal grupların yeni ulus devletleri tekfir etmelerinde ve onlara karşı İslam devrimi ile sonuçlanacağını ümit ettikleri bir savaş içine girmelerinde temel motivasyon olmuştur. Onlar ana akım İslamcıların, "şeriatın tatbiki sorunu" olarak şöhret kazanan bu gerilim meselesinde gerekli İslami hassasiyeti göstermemelerinden şikâyetçi olmuşlar ve onlara bu minvalde çeşitli tenkitler yöneltmişlerdir. Biz de çalışmamızın ikinci aşamasını bu eleştiri temasına ayırdık ve yapılan tenkitleri "din-hukuk ilişkisi bağlamında" yöneltilen tenkitler başlığı altında incelmeye tabi tuttuk.

Modern dönemde devletin ve toplumun İslamlaşması için hangi yöntemin (menhec) benimseneceği sorunsalı Müslüman toplumun çeşitli fraksiyonlara ayrılmasında en belirleyici etken olmuştur. İhvan-ı Müslimin gibi ana akım İslamcıların, İslamlaşma yöntemi olarak davet, irşat ve eğitim gibi araçları savunması ve barışçll bir yolla İslamlaşmanın tedriciliğine vurgu yapması da iki ekol arasındaki ayrışmanın temel nedenlerinden biri olmuştur. Biz de çalışmamızın son bölümünde, bir taraftan yöntem konusunda diğer taraftan da düşman olarak tanımlanan unsurlarla girişilen ilişki konusunda ana akım İslamcılara yöneltilen eleștirileri "İslamlaşma yöntemi sorunsalı ve ötekiyle olan ilişki bağlamında yöneltilen tenkitler" başlığı altında incelemeye tabi tutuk. Bu çerçevedeki eleştirilerin, ana akım İslamcıların şiddet karşıtlığı, tekfir ve düşman tanımlaması gibi konularda benimsediği tutuma karşı yapıldığını mülahaza ettik. Ayrıca dini radikalizmin düşman tanımlaması içine giren kimse ve kurumlarla İslamcıların girdiği ilişki, "müminleri dost edinmek ve kâfirlerden uzak durup onlara düşmanlık beslemek" anlamına gelen, dini metinlerde sıkça zikredilen ve dini radikalizmin temel düşünce esaslarından biri olan el-Velâ ve'l-Berâ düşüncesi zemininde tenkide tabi tutulduğunu göstermeye çalıştık. 


\section{Notlar}

1. "Lâ Dîne fi's-Siyâse".

2. "Kim Allah'ın indirdiği ile hükmetmezse kâfirlerin ta kendileridir."

3. "Ey iman edenler, Allah'a, resulüne ve sizden olan emir sahiplerine itaat ediniz..."

4. Nitekim öncü cihâdi ideolog Ebû Mus'ab es-Sûrî, İslam toplumunun içinde bulunduğu buhranın temel nedeni olarak Müslümanların İslamlaşma yöntemi hususunda yaşadığı keskin ayrışmayı görmüş ve kendilerinin takip ettiği yöntemi benimsemeyen neredeyse bütün dini grupları şu sözlerle tenkit etmiştir: "İslam ümmetinin içinde bulunduğu hal, huzur ve sükûnet içinde uykuya dalmışken ansızın hırsızların saldırısına uğrayan hane halkının durumuna benzemektedir. Haneye saldıran hırsızlardan biri babaya saldırır, diğeri anneyi yaralar, öteki kız kardeșin ırzına geçer ve bir diğeri de bir taraftan evi yağmalarken diğer taraftan da evi ateşe verir. Hane halkının neferleri sayılan erkek kardeşler ise tam bu esnada kendi işleriyle iștigal etmektedirler. Biri gece namazına kalkmış huşu içinde virdini icra etmekte ve huşunun şiddetinden olsa gerek olup biteni duymamaktadır. Diğeri uzun zamandır sıhhatini araștırdığı bir hadis senedini ilmi kitaplar arasında tahkik etmekle meşguldür. Bir diğeri ıslah olması için çabaladığı bir komşusuyla davet amaçlı olarak bir tartışmanın içine dalmıştır. Ötekisi bilgisayarın ekranın karşısına geçmiş internet üzerinden dini bir konuda yapılan açık oturumu takip etmektedir. Sonuncusu ise, gelecek seçimlerde bazı âlim ve davetçilerin aday olabilmesi için reklam ve propaganda hazırlamak için materyaller oluşturma çabası içindedir. Sadece en küçük kardeș akıtılan kanı, çiğnenen ırzı, yağmalanan malı ve yıkılmakta olan haneyi savunmakta ve diğer kardeșleri de savunmaya geçsinler diye avaz avaz bağırmaktadır. Fakat bu çağrıya ses veren hiç kimse bulunmamaktadır. Baştan aşağıya silahla donanmış bu hırsızlar karşısında tek başına mücadele eden elindeki bıçak ile bu küçük kardeștir ve zillete razı olmaktansa ölümü göze almıștır" (Es-Sûrî, 2004, 1/190-191).

5. 0 dönemde içki içilen mekânlara yapılan bireysel saldırılar kastedilmektedir.

6. Emr-i bi'l-Ma'rûf ve Nehyi 'ani'l-Munker.

7. İhvan'ın Kral Fuad ve Kral Faruk'la olan ilişkisinin geniş eleştirisi için bkz:: (Ez-Zevâhirî, 2005, 96122) .

8. İhvan'ın Hür Subaylar ve Cemal Abdunnasır'la olan ilişkisinin geniş eleștirisi için bkz.: (Ez-Zevâhirî, 2005, 122-137).

9. İhvan'ın Enver Sedat'la olan ilişkisinin eleştirisi için bkz.: (Ez-Zevâhirî, 2005, 137-142).

10. İhvan'ın Hüsnü Mübarek'le olan ilişskisinin eleştirisi için bkz.: (Ez-Zevâhirî, 2005, 142-148).

11. Vefd Partisi bașta olmak üzere İhvan'ın siyasi parti, grup ve kişilerle olan ilişkisinin geniş eleştirisi için bkz:: (Ez-Zevâhirî, 2005, 150-194).

12. “İbrahim'de ve onunla birlikte bulunanlarda sizin için güzel bir örnek vardır. Hani onlar kavimlerine “Biz sizden ve Allah’ı bırakıp taptıklarınızdan uzağız. Sizi tanımıyoruz. Siz bir tek Allah'a inanıncaya kadar, sizinle bizim aramızda sürekli bir düșmanlık ve nefret belirmiștir..." Yine Zuhruf Suresi 27. ayetinde Hz. İbrahim şöyle demektedir: "Hani İbrahim, babasına ve kavmine şöyle demişti: Şüphesiz ben sizin taptıklarınızdan uzağım."

13. Ayrıca ana akım İslamcıların bu barışçl yaklaşımları bazı cihadî ideologlar tarafından Batı́nın "lımlı İslam" projesine bir katkı olarak da görülmüş ve ana akım İslamclar bu cihetten de tenkide tabi tutulmuştur (Es-Sibâ'i, ts., 1-3).

14. El-Makdîsî bu görevleri üstlenen kimselerin durumu konusunu tartışırken temkinli davranmaktadır. Yapmaya çalıșmak istediği şeyin belli kişileri tekfir etmek anlamına gelen "muayyen tekfir" olmadığı; belli bir amelin tekfiri olan "mutlak tekfir" olduğunu vurgulamaya çalışmıştır. Öte yandan bütün bu vazifelerin hepsinin de küfür ve şirke sebebiyet vermediği, bazılarının günah bazısının büyük günah ve kalan bazılarının da șirke ve küfre götüren vazifeler olduğunu ifade etmiş̧ir (El-Makdîsî, 1988, 130-131).

15. İhvan'nın ikircikli tutumu hakkında bilgi için bkz.: (El-Lecnetu'ş-Şer'iyye, ts., 34-35). 


\section{Kaynakça}

Abdurrahman, Ömer. Kelimetu Hakk. Kahire: Dâru'l-İtisâm, (ts.).

El-Lecnetu'ş-Şer'iyye bi-Cemâ'ati'l-Cihâd. Fethu'r-Rahman fî'r-Reddi 'alâ Beyâni'lİhvân. Word: Minberu't-Tevhîd ve'l-Cihâd. http://www.ilmway.com/site/maqdis/MS_27166.html

El-Lîbî, Ebû Yahya. Ed-Dîmukrâtiyye: es-Sanamu'l-Âsrî. PDF: Minberu't-Tevhîd ve'lCihâd,_(ts.). http://www.ilmway.com/site/maqdis/MS_742.html

El-Makdîsî, Ebû Muhammed. Ed-Dîmukrâtiyye Dînun. Word: Minberu't-Tevhîd ve'lCihâd, (ts.). http://www.ilmway.com/site/maqdis/MS_26238.html

El-Makdîsî, Ebû Muhammed. Milletu İbrahim ve Da'vetu'l-Enbiyâi ve'l-Murselîn. Word: $\quad$ Minberu't-Tevhîd ve'l-Cihâd, 1984. http://www.ilmway.com/site/maqdis/MS_20383.html

El-Makdîsî, Ebû Muhammed. Keşfu'n-Nikâb 'an Şerî'ati'l-Ğâb. Word: Minberu'tTevhîd ve'l-Cihâd, 1988. http://www.ilmway.com/site/maqdis/MS_38438.html

Es-Sibâ'î, Hânî. Risâla Hâdi'a li-Kâdeti'l-İhvâni'l-Muslimîn: Eyyu'l-Menheceyni Ahakkun bi'l-Ittibâ'. Word: Minberu't-Tevhîd ve'l-Cihâd, 2006. http://www.ilmway.com/site/maqdis/MS_19821.html

Es-Sibâ'î, Hânî. El-Meşrû'ul-Amrîkîyyi'l-Cedîd: "El-İslâmu'l-Mu'tedil". Word: Minberu't-Tevhîd ve'l-Cihâd, http://www.ilmway.com/site/maqdis/MS_21842.html

(ts.).

Es-Sûrî, Ebû Mus'ab. Da'vetu'l-Mukâvemeti'l-İslâmiyyeti'l-'Âlemiyye (el-Cuzûr ve'tTârîh ve't-Tecârib). Word:_Minberu't-Tevhîd ve'l-Cihâd, 2004. http://www.ilmway.com/site/maqdis/MS_808.html

Eş-Şankîtî, Ebu'l-Munzir. İslâmiyyûn fî Vahli'd-Dîmukrâtiyye. Word: Minberu'tTevhîd ve'l-Cihâd, 2011. http://www.ilmway.com/site/maqdis/MS_737.html

Eş-Şankîtî, Ebû Abdurrahman. Tehâfutu'd-Dîmukrâtiyyîn. Word: Minberu't-Tevhîd ve'l-Cihâd, (ts.). http://www.ilmway.com/site/maqdis/MS_12393.html

Et-Tartûsî, Ebû Basîr. Hazihi Hiye'd-Dîmukrâiyye: Fehel Entum Muntehûn. Word: Minberu't-Tevhîd ve'l-Cihâd, http://www.ilmway.com/site/maqdis/MS_26178.html

1999.

Et-Tartûsî, Ebû Basîr. İhfâkâtu'l-Hareketi'l-İslâmiyyeti'l-Mu'âsıra (el-Esbâb ve'd-Difâ' ve'l-'illâc). $\quad$ Word: $\quad$ Minberu't-Tevhîd ve'l-Cihâd, 2005. http://www.ilmway.com/site/maqdis/MS_27164.html

Ez-Zevâhirî, Eymen. El-Hasâdu'l-Murr: el-İhvani'l-Müslimin fi Sittîne 'Âmen. Word: es-Samûdu'l-İlâmiyye. $2 . \quad$ Basım, 2005. http://www.ilmway.com/site/maqdis/MS_25064.html

Kutub, Seyyid. El-Me'âlim fi't-Tarîk. Kahire: Dâru'ş-Şurûk, 1979.

Mercan, M. Hüseyin. Müslüman Kardeșlerin Yükselişi ve Düşüşü: İslami Hareketlerde Siyasi Kurumsallaşma Sorunu, İstanbul: İLEM, 2019. 